\title{
Deterioration of Natural Forests by Displacements at Al Genaina Locality, Al Genaina State, Sudan
}

\author{
Ismail Mohamed Fangama $^{1^{*}}$ and Fatah Al Rahaman Bakheet ${ }^{2}$ \\ ${ }^{I}$ Department of Plant and Environment, College of Forestry and Range Science, SUST \\ ${ }^{2}$ Ministry of Agriculture and Forestry, Genaina \\ *Corresponding author
}

\section{A B S T R A C T}

\section{Keyw ords \\ Deterioration, Dominant, \\ Density and natural forests \\ Article Info \\ Accepted: \\ 24 September 2018 \\ Available Online: \\ 10 October 2018}

The research was carried out at the internally displacement persons camps around $\mathrm{Al}$ Genaina Locality. Its objectives are to assess the status of natural forests so as to know the density of trees, their types and distribution in the study area. The activities of displacements in the area caused the deterioration of natural forests. Point-Centered Quarter Method (PCQ) was used to calculate the trees density. The results showed that the tree density was five trees per hectare. Clotropis procera became the dominant species in the study area due to continuous cutting down of tees. The study concluded that the trees were completely degraded in research area. The study recommended that, planting cleared area and protecting remaining trees in displacements areas.

\section{Introduction}

In Numili on the border with Uganda, for instance the illicit felling of trees for firewood and to clear land for slash- and burn agriculture on the outskirts of local IDPs camp has resulted in the deforestation of large area surrounding the camps (Agenes, 2007). Around Kass displacements camps, the study revealed that the density of natural forests was only one tree per hectare. Because the continuous cutting down of trees by IDPs deforested the area (Abdabari, 2012). The degradation of forest land attracted attention because of these great influences on increasing run-off erosion, carbon dioxide concentration, local region and global climate change, hydrology land and loss of biodiversity
(Myers, 1988). Western Africa is a classical arena where refugees have impacted negatively on different types of natural resources, as over one million Sierra Leonean and Liberian refugees fled across their borders within the Upper Guinea forest regions of Guinea and Cote d'Ivoire with fabulous tropical rainforest, clearing forests for farmland, felling trees for the construction of refugee camps, logging and mining (Bishop and Garnett, 2000: 8). This is the stereotypical example of refugees' environmental impact everywhere even without empirical research to support it. A UNEP rapid assessment of the impacts of refugees on the environment in Guinea, through interviews, field visits and available reviewed materials reported overexploitation and consequent degradation of 
natural resources and the disruption of traditional practices in refugee-hosting areas, with the depleted vegetation cover used for the housing construction, firewood and charcoal, both for domestic use and cash generation (UNEP, 2000: 2). A study of the Senegal River Valley found changes in vegetation and land cover, which depicted declining stands of vegetation in all ecological zones along the river (Black and Sessay, 1996: 61-64).

Hassan (2016), assessed the degradation of Alnour Reserved Forest in the Sudan. He explained that the forest was subjected to heavy cutting by displacement persons settled inside the forest and the density of trees remained was four trees per hectare.

\section{Research objectives}

The objectives of the research were as the following:

To identify the dominat trees species in study area.

To assess the types, distribution and density of trees in the area.

\section{Materials and Methods}

According to (Mullre, 1974), Point-CenteredQuartered Method (PCQ) was used to assess the density of vegetation cover. Randomly, points located within the vegetation stands. Then the hundred meters transect tape was used to stand (10000 meters). The meter tape was stretched to its full length. At each 10 meters of the tape, sample points were marked at intervals along the tape where an individual tree was sample once at successive points. At each sample point four quadrants (NE, SE, $\mathrm{SW}$, and $\mathrm{NW}$ ) was defined and then the distance from the sample point to the tree was recorded the process was repeated for three times, and then the average for points were obtained. The records of each sample were arranged in table. Then the vegetation parameters were calculated according to the following equations:

Step 1: Calculation of the total distance (dt)

$$
\mathrm{dt}=\sum_{\mathrm{i}-1}^{\mathrm{N}} \mathrm{di}=\ldots . \text { meters }
$$

Step 2: Calculate the average distance between trees $\left(\mathrm{d}^{-}\right)$

$\mathrm{D}=\mathrm{dt} / \mathrm{n} \ldots . .$. meters.

Step 3: Calculate the average area occupied per tree. (A)

$\mathrm{A}=\mathrm{d}^{2-} \ldots$ meters $^{2}$.

Step4: Calculate the absolute density for all trees, (Da) number of trees per hectare

$\mathrm{Da}=(10 \mathrm{~m})^{2} / \mathrm{A}^{2}=\ldots$..trees $/$ ha.

\section{Results and Discussion}

The results showed that the average density is equal to about 5 trees/ ha in the study area. This revealed that the natural forests were subjected to severe degradation due to displacements activities, such as cutting down trees for firewood, charcoal and building materials (Table 1 and plates 3, 4, 5 and 6). This finding resembles to result obtained by Abdabari (2012), the density of natural forests was only one tree per hectare around Kass displacements camps. Because the continuous cutting down of trees by IDPs deforested the area. Also ageed with the study of Hassan (2016), the degradation of Alnour Natural Reserved Forest in the Sudan was subjected to heavy cutting by displacement persons settled inside the forest and the density of trees remained was four trees per hectare. 
Table.1 Total distances record between random points and trees in study area 2017

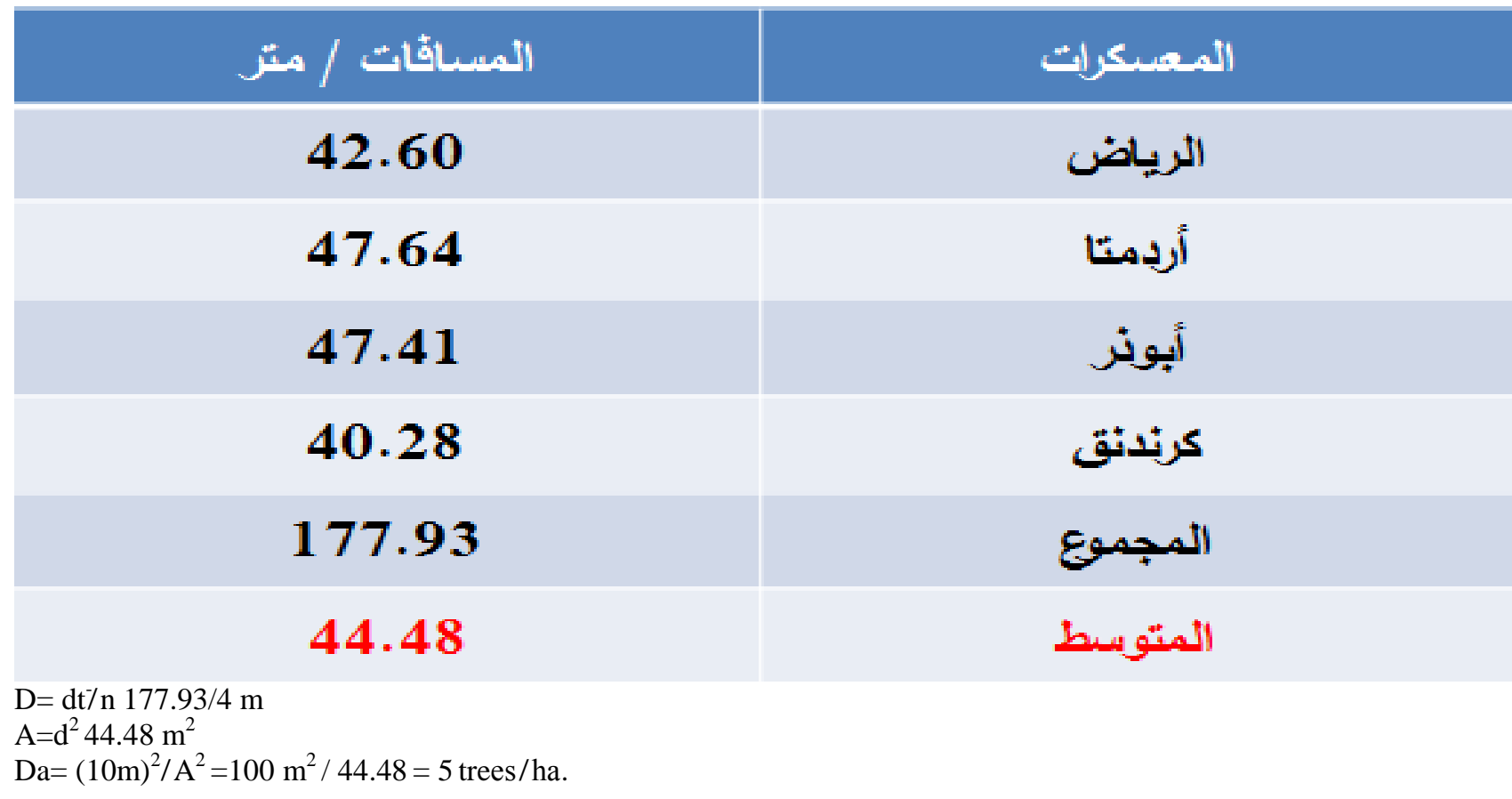

Table.2 Distribution of trees in the study area 2017

\begin{tabular}{|c|c|c|c|}
\hline$\%$ & ألكرارلك & الإسم اللاحتيثي & الثوع \\
\hline 37.05 & 176 & Calatropis procera & العُّر \\
\hline 37.26 & 177 & Boscia senegalensis & المخيط \\
\hline 0.21 & 1 & Ezdirakhta indica & الثيخم \\
\hline 1.68 & 8 & Coleus barbatus & 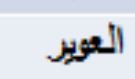 \\
\hline 0.84 & 4 & Acacia albida & الحرز \\
\hline 0.21 & 1 & Cassia siamea & الكاعبيا \\
\hline 6.52 & 31 & Balanites aegyptiaca & الهجليج \\
\hline 2.32 & 11 & Acacia senegal & الهُّنب \\
\hline 2.32 & 11 & Zizuphus spina -cristi & المنر \\
\hline 4.21 & 20 & $\begin{array}{l}\text { Albizzia amara subsp. } \\
\text { sericocephal }\end{array}$ & العزد \\
\hline 7.16 & 34 & Aerva javonica & الفيش \\
\hline 0.21 & 1 & Acacia seiberian & الكولك \\
\hline 99.9 & 475 & & المجموع \\
\hline
\end{tabular}


Plate.1 Building poles fetched from far distances (2017)

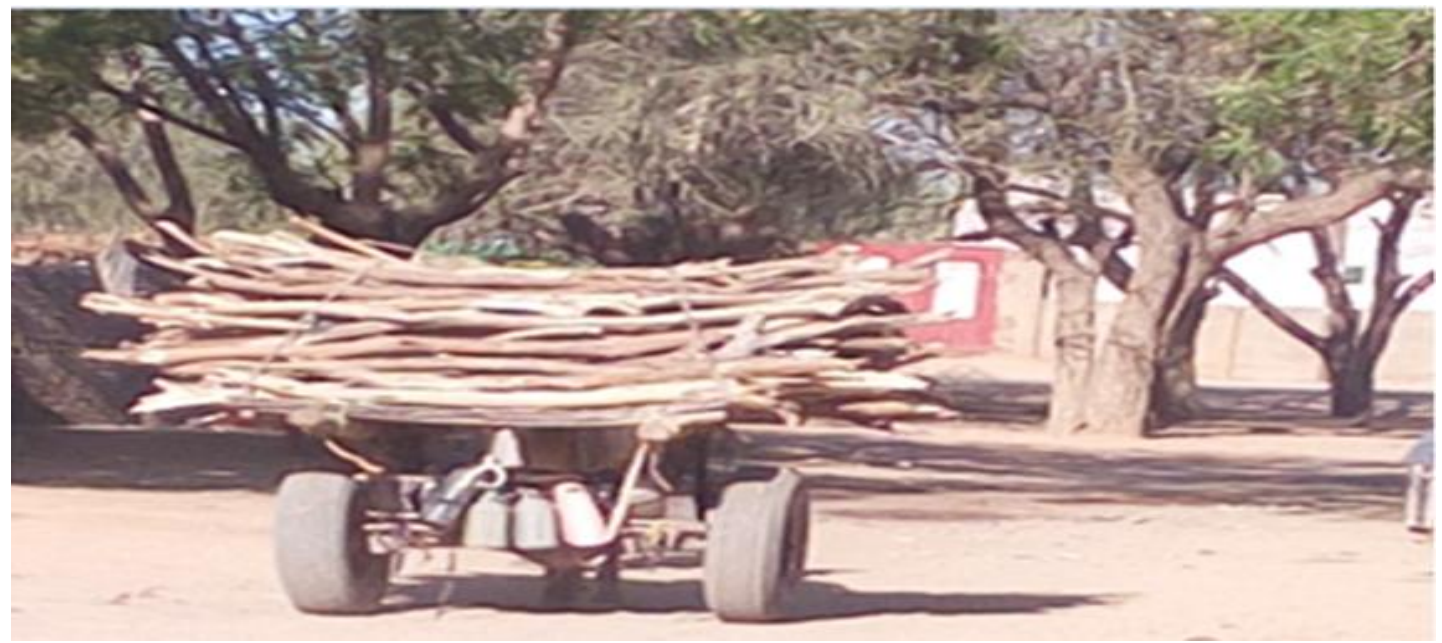

Plate.2 Charcoal manufacturing from trees of natural forests (2017)

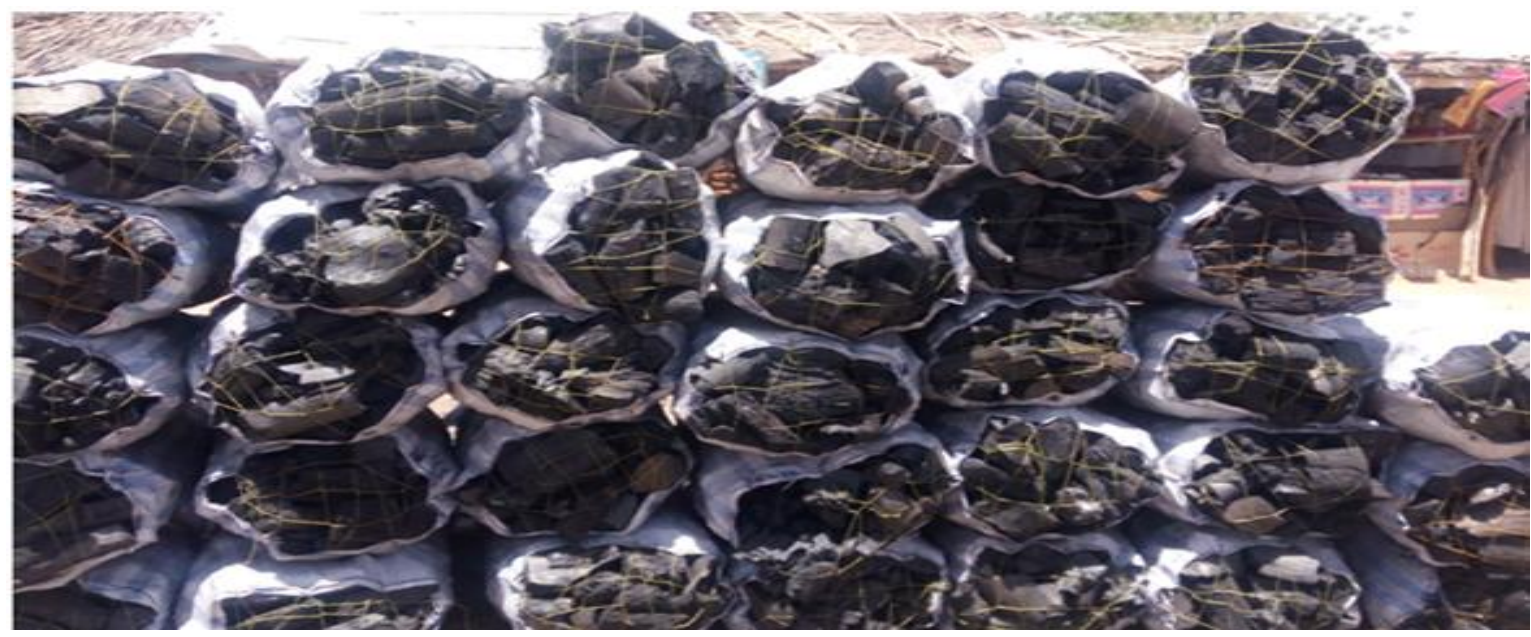

Plate.3 Displacement women fetched firewood from far distances (2017)

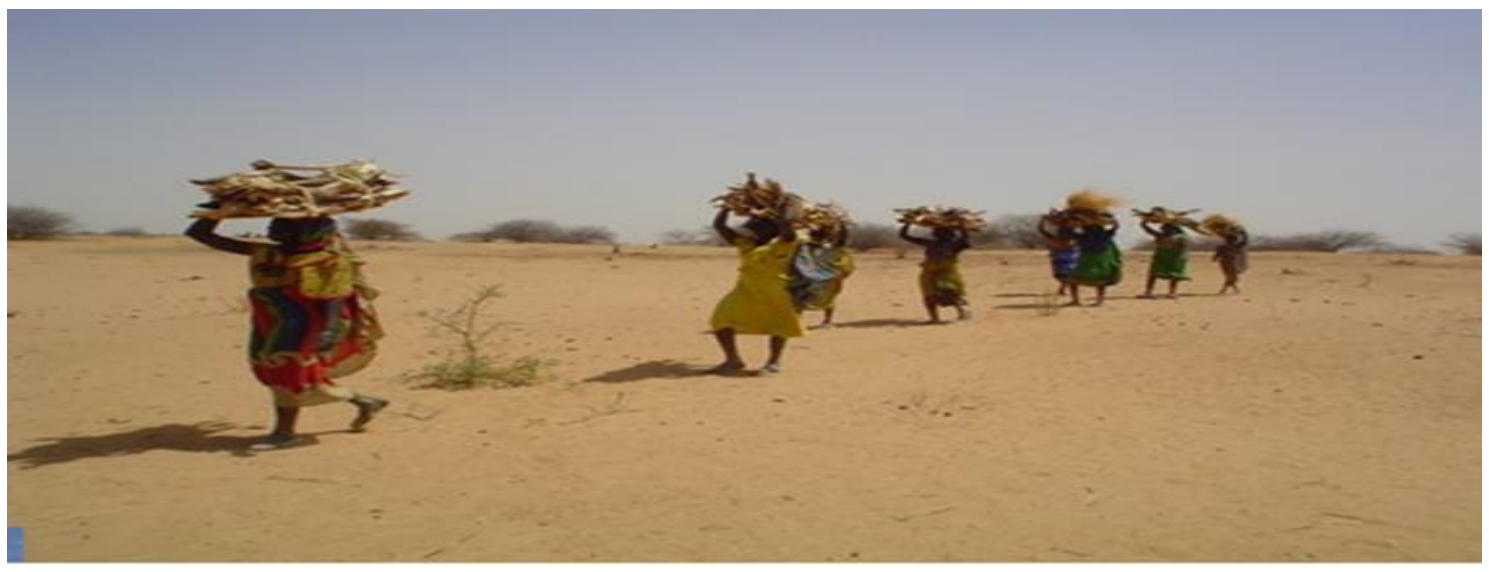


Plate.4 Quantity of fire wood in the market (2017)

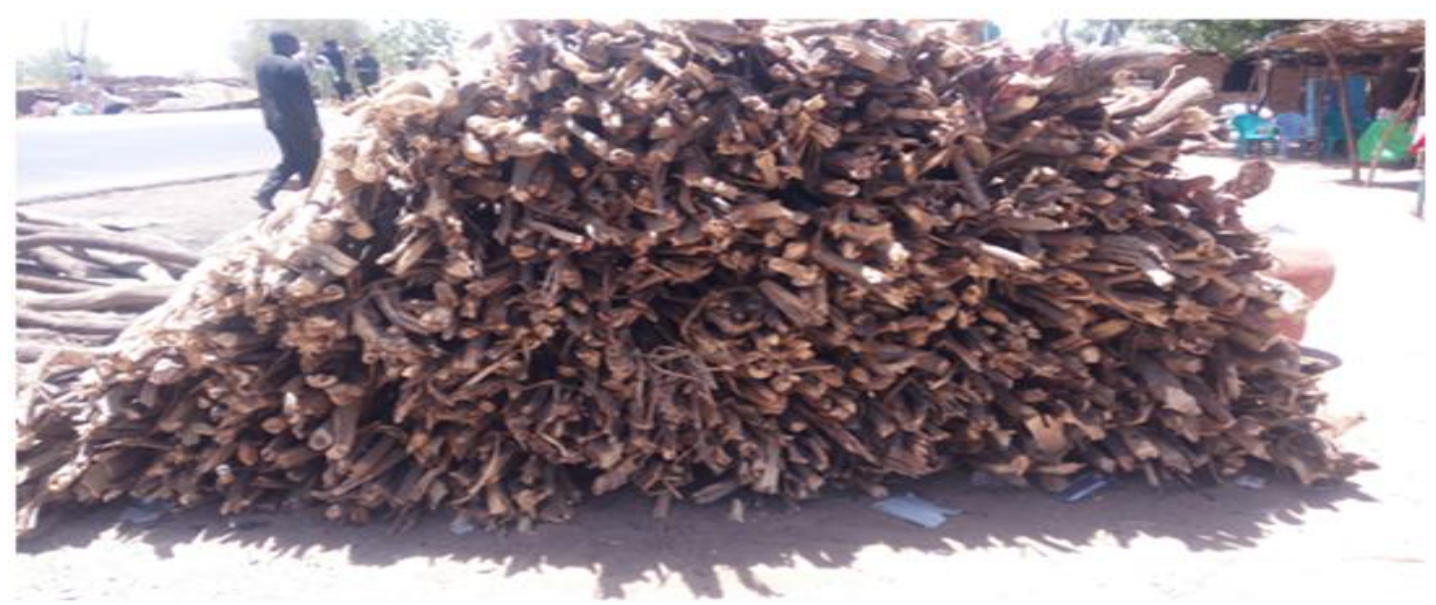

Plate.5 Presence of Coltropis procera is a sign of degradation in the area (2017)

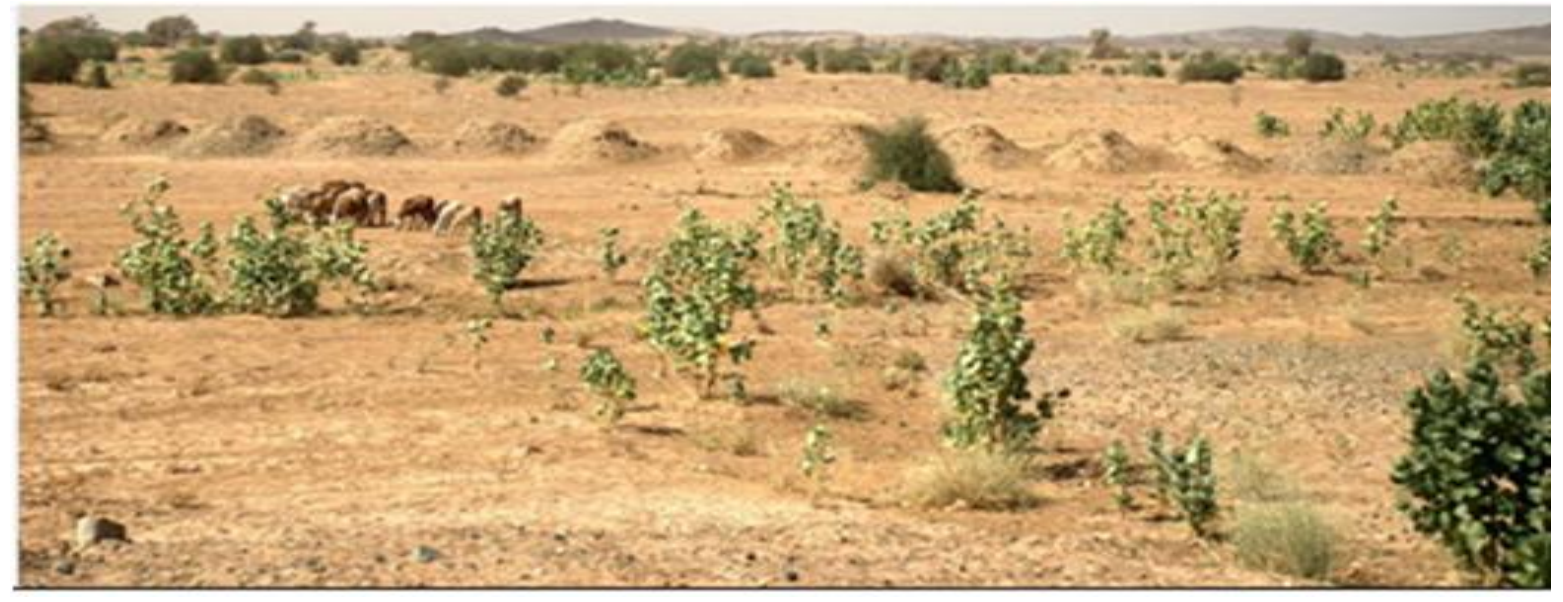

Plate.6 Coltropis procera is a dominant species (2017)

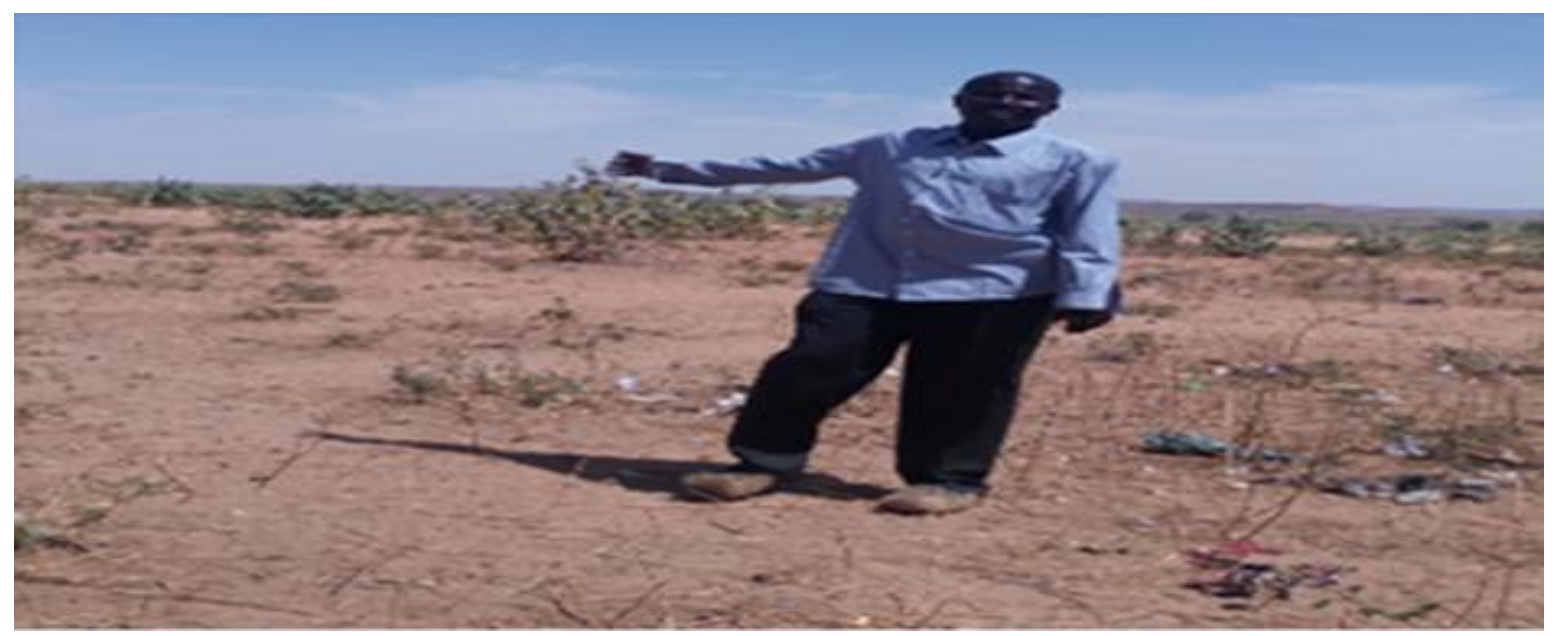


Plate.7 Large area with scatter trees (2017)

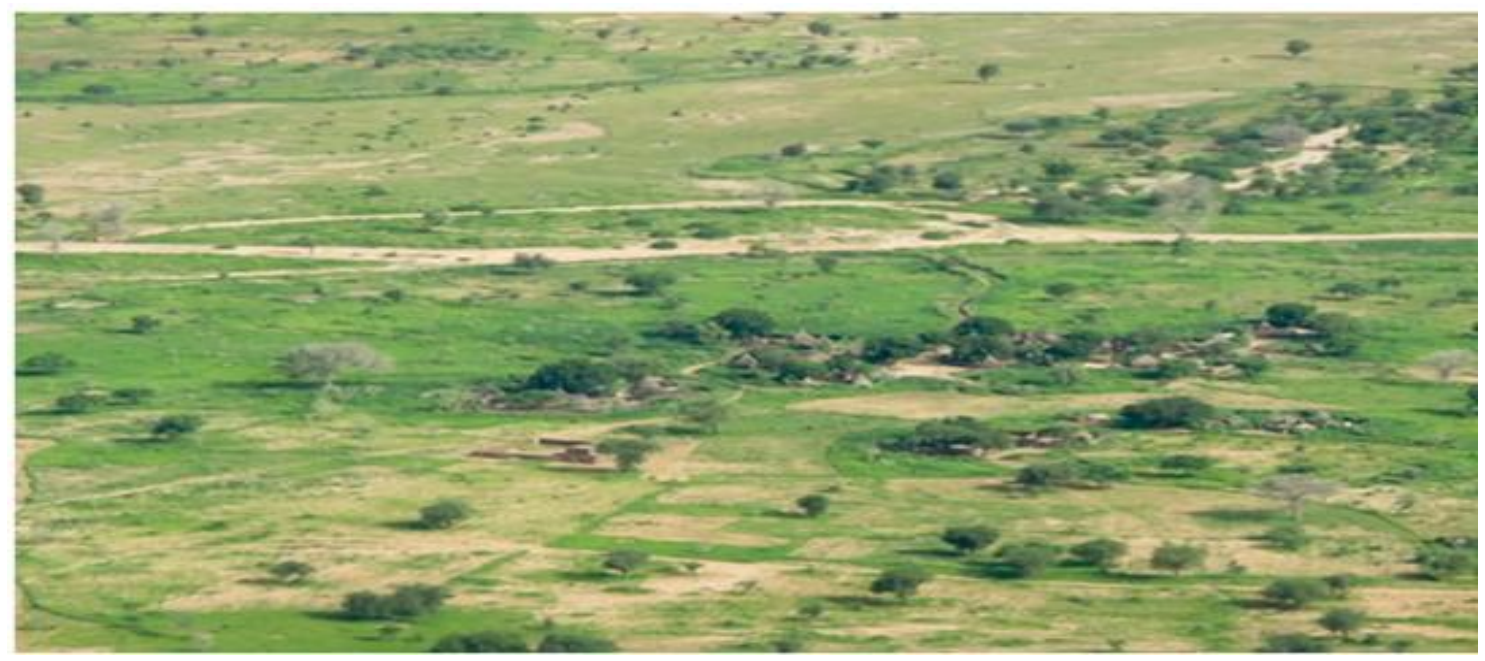

On the other hand the results revealed that Bossica seneglensis and Calatropis procera were the dominant species in the study area with frequencies $37.26 \%$ and $37.05 \%$ respectively. While the species of Balanites aegyptiaca, Ziziphus spina-cristi, Acacia senegal and Acacia albida were showed lower frequencies equal to $6.52 \%, 2,32 \%$, $2.3 \%$ and $0.84 \%$ respectively (Table 2 ). The study concluded that the natural forests in the study area were degraded due to trees cutting down by displaced persons for firewood, building materials and charcoal. There were some trees scattered in the area. This degradation leads to desertification of the area.

\section{Recommendations}

The study recommended the following:

Planting cleared area

Protecting remaining trees in displacements areas

Using alternative fuels to decrease the consumption of wood.

\section{References}

Abulmotalib, O. A. (2012). Impact of Displaced People on Natural Forests at Kass Camp. South Darfur State. Msc. In Environmental Forestry. College of Forestry and range Science. Sudan University of Science and Technology. Khartoum, Sudan.

Agenes, G. (2007). From Internal to International Displacement in Sudan. paper prepared for the migration and refugees movements in the Middle East and North Africa. The forced migration and refugees studies program, the American University in Cairo, Egypt.

Bishop, T. and Garnett, T. (2000) Civil Conflict and the Environment in the Upper Guinea Forest of West Africa; West Africa Trip Report. Washington, D.C.: Biodiversity Support Program, Disasters and Biodiversity Project and USAID.

Black, R. and Sessay, M. (1996) "Refugees, land cover, and environmental change in the Senegal River Valley", Geo Journal 41 (1): 55.67).

Hassan, H. E.N. (2016). Assessment the degradation of Alnour Natural Reserved 
Forest in Alroseires Locality, Blue Nile State, Msc. In Environmental Forestry. College of Forestry and Range Science. Sudan University of Science and Technology. Khartoum, Sudan.

Myer, N. (1988). Tropical Forests: much more than stocks of wood. Journal of Tropical Ecology. 4, 209-221.
United Nations Environment Programme UNEP (2000). Report of the Brainstorming on Environmental Impact of Refugee Settlement and Flows in Africa, UN Compound, Gigiri, Nairobi, Kenya, 14-15 September.

\section{How to cite this article:}

Ismail Mohamed Fangama and Fatah Al Rahaman Bakheet. 2018. Deterioration of Natural Forests by Displacements at Al Genaina Locality, Al Genaina State, Sudan. Int.J.Curr.Microbiol.App.Sci. 7(10): 3207-3213. doi: https://doi.org/10.20546/ijcmas.2018.710.372 